\title{
The Great Silver Smelt, Argentina silus, Nilss. An Addition to the List of British Fishes.
}

By

\author{
Ernest W. L. Holt.
}

By the kindness of Mr. J. Jacobs, to whom the Laboratory is already indebted for many specimens of interest, I received on the 15 th June a fine example of the species mentioned above, which had been trawled off the south coast of Ireland. The fish weighed $1 \mathrm{lb} .5 \mathrm{oz}$, and measured $42 \mathrm{~cm}$, or $16 \frac{1}{2}$ inches. Though taken at least a day previously, it was in excellently fresh and firm condition. I have already recorded its capture in a letter to the Field and at a meeting of the Zoological Society, but the locality was inexactly given in each of these communications. I have since learned that the correct locality is $50^{\circ} 20^{\prime} \mathrm{N}$., $8^{\circ} 25^{\prime} \mathrm{W}$., or about seventy-five miles true S. of the Old Head of Kinsale, depth seventy-four fathoms. A number of the same species were trawled, and some were found to be excellent eating. I have no means of deciding whether the occurrence of $A$. silus on the ground indicated is normal or exceptional. If it can be taken in any quantity it should prove a valuable addition to our list of food-fishes.

I can find no previous record of $A$. silus in British waters, since Edward, according to Day, acknowledged that his specimen was identical with the species figured and described by Day, which is the lesser silver smelt, $A$. sphyroena, Linn. Other European records are from the Scandinavian and Jutland coasts, always in water of considerable depth. The species is also known from the Atlantic coasts of North America. A good figure is given by Smitt (Hist. Scand. Fish., Ed. 2, II.), who states that all the examples of which he has acquaintance had the stomach everted by the expansion of the airbladder, and so yielded no evidence as to the nature of the food. In my specimen the air-bladder was not abnormally dilated, and the osophagus and stomach were filled with a mass of finely triturated animal matter, which appeared, judging from experience in similar 
cases, to be the muscular tissue of shrimps or prawns. A much macerated telson, the only hard part found, appeared to belong, most probably, to a shrimp, certainly to that section of the Crustacea macrura which embraces the shrimps and prawns. I also found a single copepod, identified by Mr. T. V. Hodgson as Calanus finmarchichus. The latter is often met with at the bottom, and has been found by myself in the stomachs of pleuronectids, while all available evidence seems to indicate that $A$. silus is a bottom-haunting fish.

Ichthyologists will observe that this record sensibly extends the range of $A$. silus in a southerly direction. Comment on the matter may well be withheld until we possess even an elementary knowledge of the fauna of the deeper parts of our own region. It is hardly necessary to add that the specimen has been handed over to the custody of the British Museum. 